\title{
Methylene Tetrahydrofolate Reductase Gene Polymorphism and the Risk of Ischemic Stroke in Type 2 Diabetic Egyptian Patients
}

\author{
Amal M. H. Mackawy (Corresponding author) \\ Department of Medical Biochemistry, Faculty of Medicine, Zagazig University \\ Tel: 96-650-812-9407Ｅ-mail: amalmackawy@yahoo.com \\ Mohammad Badawy \\ Department of Internal Medicine, Faculty of Medicine, Zagazig University Hospitals \\ Tel: 96-659-434-0162Ｅ-mail: badawi_ms@yahoo.com
}

Received: June 9, 2011 Accepted: June 29, 2011 doi:10.5539/gjhs.v3n2p162

\begin{abstract}
Background: A common C677T mutation of methylenetetrahydrofolate reductase (MTHFR) gene is reported to be associated with hyperhomocysteinemia a risk for atherosclerotic vascular diseases and ischemic stroke (IS). Aim: To clarify the possible role of the MTHFR $677 \mathrm{C}>\mathrm{T}$ polymorphism in predisposition to IS and to assess the relationship of allelic variants of MTHFR gene with homocysteine (Hcy) plasma levels and other risk factors of atherosclerosis and IS in type 2 diabetic Egyptians. Subjects: Group I: 40 healthy non diabetic volunteers. Group II: 40 patients with type 2 diabetes mellitus (DM) without IS. Group III: 40 patients with type 2 DM and IS. Methods: Fasting blood samples were collected for research investigations. HPLC technique was used to estimate plasma Hcy levels. Polymerase chain reaction (PCR) assay with restriction fragment length polymorphism (RFLP) were used to examine the MTHFR polymorphism. Results: The frequencies of T allele and TT genotype were significantly higher in group III patients when compared to group I and group II $(\mathrm{P}<0.001)$.Total plasma Hcy and uric acid levels were significantly higher in group III patients who carry the TT genotype. Conclusion: The MTHFR 677C>T polymorphism is associated with elevated Hcy and uric acid plasma levels which increases the atherogenic risk and the prevalence of IS in type 2 diabetic Egyptian patients.
\end{abstract}

Keywords: MTHFR gene polymorphism, Type 2 diabetes mellitus and ischemic stroke

\section{Introduction}

Diabetes mellitus (DM) is a multifactorial and polygenic disease which is considered as a major life threatening problem all over the world (Audelin et al., 2001). Cardiovascular disease (CVD) and ischemic stroke (IS) are the main complications of diabetes mellitus (DM) (Ozmen et al., 2002). IS is referring to prolonged ischemia arising from sudden occlusion of cerebral artery and considered as a leading cause of death in developed countries (Kothari et al, 2002). There are multiple risk factors which may contribute to macrovascular and microvascular problems in DM such as hyperglycemia, hypertension and dyslipidemia (Angeline et al., 2005). The high risk for IS in patients with type $2 \mathrm{DM}$ is partly explained by all of these risk factors that have genetic determinants and may accelerate diabetes-induced atherosclerosis (Zhaohui et al .,2003) . MTHFR enzyme is responsible for methylation of homocysteine (Hcy) to methionine (Ralph and Jacobsen, 2001). MTHFR 677C >T (Ala222Val) single nucleotide polymorphism (SNP) is associated with reduced enzyme activity, resulting in a relative deficiency in the remethylation process, leading to hyperhomocysteinemia among carriers of the CT and TT genotypes (Aguilar,2004) . Hyperhomocysteinemia may promote vascular disease through endothelial injury, predisposing the vessel to atherosclerosis (Pollex et al., 2005) and appears to be significantly associated with atherosclerosis and IS in type 2 DM (Eikelboom et al., 2000).

A direct relation was observed between plasma Hcy and plasma uric acid levels in patients with atherosclerosis indicating the strong association between the two biochemical variables in the presence of homozygosity for MTHFR T allele. This could increase the availability of 5, 10-MTHF for the de novo synthesis of purines via 10formyl THF causing uric acid over production (Motti et al., 1998). Hyperuricemia is commonly associated with other known risk factors for CVD, such as obesity, hyperlipidemia, and hypertension (Malinow et al., 1995). 


\section{Aim of the work}

The objective of this study was to investigate a possible role of the MTHFR 677C $>\mathrm{T}$ gene polymorphism in predisposition to IS in Egyptian patients with type 2 DM. Moreover, to assess the relationship of allelic variants of MTHFR gene with Hcy plasma levels and with other risk factors associated with the incidence of atherosclerosis and IS in type 2 diabetic Egyptian patients.

\section{Subjects and methods}

This study was carried out in the Medical Biochemistry, Internal Medicine, Departments, Faculty of Medicine, Outpatients Clinics and Intensive Care Unit of Zagazig University Hospitals during the period from July 2009 to July 2010. In this study we investigated the effect and relationship of allelic variants of the MTHFR gene in Egyptian diabetic patients with and without IS. A polymerase chain reaction (PCR) with restriction fragment length polymorphism (RFLP) was used to detect gene polymorphism. All diabetic subjects were diagnosed according to World Health Organization (WHO) criteria on regular follow in diabetic Outpatients Clinics, Zagazig University Hospitals. The duration of diabetes mellitus was determined by reviewing the clinical history and the medical records, they were suffered from DM more than 15 years.

\subsection{Subjects}

This study comprised of 120 recruited subjects. They were classified into three main groups:

Group I: 40 normal volunteers (19 females and 21 males). Their mean ages were ranged from $42.0-63.0$ years with a mean value \pm S.D of $53.17 \pm 5.73$ years. Who had been matched for BMI, sex, age and socioeconomic background, they had no evidence of IS risk factors, such as DM, hypertension, obesity, hypercholesterolemia, family history or previous history of stroke or transient ischemic attacks and smoking on the basis of their clinical history and physical examination.

There was no statistical difference $(\mathrm{P}>0.05)$ in control group regarding age and sex .They were recruited from Outpatients Clinics, Zagazig University Hospitals.

GroupII "Type 2 diabetic patients without IS": included 40 patients aged from 43.0-64.0 with a mean value \pm S.D of $52.81 \pm 5.4$ years (23 males and 17 females). They were diagnosed as diabetic patients as fasting blood glucose (FBG) level is equal or more than $126 \mathrm{mg} / \mathrm{dl}$ (Trinder, 1969).

Group III "Type 2 diabetic patients with IS": comprised 40 patients with ages ranged between 45.0 - 63.0 years with a mean value \pm S.D of $54.03 \pm 5.03$ years (22 males and 18 Females). The diagnosis of IS was considered when neurological deficits were accompanied by the corresponding abnormalities on CT of the brain (Gharib et al., 2005). Patients with cerebral hemorrhage and atrial fibrillation were excluded. Similarly subjects with overt nephropathy with serum creatinine above $178 \mu \mathrm{mol} / \mathrm{L}(2 \mathrm{mg} / \mathrm{dL})$, were also excluded to eliminate other risk factors for embolic IS. Serum creatinine considered normal in men $136 \mu \mathrm{mol} / \mathrm{L}(1.5 \mathrm{mg} / \mathrm{dl})$ and women 120 $\mu \mathrm{mol} / \mathrm{L}(1.4 \mathrm{mg} / \mathrm{dl})$ (Bartels et al., 1972).

All patients were assessed as having risk factors for IS, such as DM, hypertension, obesity, hypercholesterolemia, family history or previous history of stroke or transient ischemic attacks and smoking. All those with systolic blood pressure $>140 \mathrm{mmHg}$ and/or diastolic blood pressure of $90 \mathrm{mmHg}$ or those on regular antihypertensive medications were classified as hypertensives. Hypercholesterolemia was considered when total cholesterol (TC) levels $>240 \mathrm{mg} / \mathrm{dl}$. A body mass index (BMI) of $>30 \mathrm{Kg} / \mathrm{m}^{2}$ was classified as obese. BMI was computed as weight $(\mathrm{kg})$ divided by square height $(\mathrm{m} 2)$. Subjects were considered smokers if they had been smoking cigarettes regularly (one or more per day) (Perwaiz et al., 2005).

There was no statistical difference $(\mathrm{P}>0.05)$ between all groups regarding age and sex. Informed consent was obtained from all the participants in this study. The characteristics of all groups are tabled in table 1.

\subsection{Sample collection}

Overnight fasting venous blood samples were collected from the subjects in EDTA containing tubes using standardized protocol and equipment., separated into two samples one whole blood for DNA extraction and MTHFR gene detection and the other plasma specimen for measuring Hcy, uric acid levels as well as other basic biochemical blood tests, were measured by standard chemical and enzymatic commercial methods in the Medical Biochemistry department and hospital laboratories.

\subsection{Methods}

All cases were subjected to the followings

(1) Thorough history taking and complete clinical examination. 
(2) Electro cardiogram (ECG) and Chest x-ray.

(3) Cranial computed tomography (CT) for diabetic patients with IS.

(4) Laboratory investigations, including:

(a) Random and fasting blood glucose levels.

(b) Lipid profile: plasma levels of total cholesterol (TC), LDL cholesterol (LDL-C) and HDL-C (Assmann et al., 1983).

(c) Plasma uric acid determination (Fossat et al., 1980).

(d) Blood urea (Chaney and Marbach, 1962) and creatinine (Bartels et al., 1972).

HPLC estimation of plasma Hcy levels (Ubbink, 1991).

\subsubsection{Standard and reagents}

(1) D. L HCY was purchased from sigma (St. Louis, Mo, USA). (2) Ammonium 7- Flourobenzo -2- oxa- 1, 3 diazole -4- sulphonate (SBD-F) was purchased from Wako (Dus seldorf, Germany). (3) Tri-n-butyl phosphine and Dimethyl formamide were purchased from Sigma. (4) Chemical reagents of mobile phase (orthophosphoric acid, potassium dihydrogen phosphate, and acetonitrile were purchased from Merck (Darmstadt, Germany). All the chemicals and solvents were of HPLC reagent grade.

Analytical Procedure/Sample preparation (Araki and Sako, 1987).

Serum and standard Hcy were derivatized with SBD-F according to the method described by Araki and Sako, 1987, as follows $0.3 \mathrm{ml}$ of plasma or standards were added to $30 \mu \mathrm{l}$ of $10 \%$ tri-n-butyl phosphine solution in dimethyl formamide. The mixture was incubated at $4^{\circ} \mathrm{C}$ For 30 minutes to accomplish reduction of thiolamines. Subsequently, $0.3 \mathrm{ml}$ of $10 \%$ trichloroacetic acid (TCA) containing $1 \mathrm{mmoL} / \mathrm{L}$ NaEDTA was added. After centrifugation, $100 \mu \mathrm{l}$ of clear supernatant were added to a mixture of $20 \mu \mathrm{l}$ of $1.55 \mathrm{~mol} / \mathrm{l} \mathrm{NaOH}, 250 \mu \mathrm{L}$ of 0.125 $\mathrm{mol} / \mathrm{L}$ borate buffer (pH 9.5) containing $4 \mathrm{mmoL} / \mathrm{L}$ EDTA and $100 \mu \mathrm{l}$ of SBD-F solution $(1 \mathrm{mg} / \mathrm{ml}$ dissolved in borate buffer). The mixture was incubated for 1 hour at $60^{\circ} \mathrm{C}$ to accomplish complete derivatization of HCY and other thiols. $20 \mu \mathrm{l}$ aliquots were subsequently used for HPLC analysis.

HPLC and derivatized thiolamines analysis:

Derivatized Hcy was analysed by HPLC. Instrument used was Perkin Elmer model LC 1020 plus, carried out on a gradient pump (Binary LC pump 250) LC 18 column (particle size $3 \mu \mathrm{m}, 3 \mathrm{~cm}$ x $4.6 \mathrm{~mm}$ inner diameter, Supelco Inc., Supelco park, Bellefonte, PA USA). The separation of thiolamines mixture carried out using $0.1 \mathrm{moL} / \mathrm{L}$ Potassium dihydrogen phosphate buffer $(\mathrm{pH} 2.1$ ) adjusted with orthophosphoric acid containing $4 \%$ acetonitrile as a mobile phase at a flow rate of $1.00 \mathrm{ml} / \mathrm{min}$.

The present work was carried out according to method described by Ubbink et al ., 1991 but with the use of UV/visible spectrophotometer detector (Model LC 290, Perkin Elmer) instead of fluorescence detector due to accidental problems had occurred in the detector. UV detector was set at different wavelengths and a wavelength $270 \mathrm{~nm}$ was selected as it gives the maximum absorption of standards.

Separate standard for Hcy was injected to determine its retention time. Then $20 \mu \mathrm{L}$ of each sample was injected. The Hcy peaks were identified on the basis of their retention times. Identity of the resolved HCY was confirmed by addition of small amount of HCY to both control and patient sample where peak enlargement was observed. The retention time of HCY was observed to be $2.1 \mathrm{~min}$.

Detection of MTHFR gene polymorphism: Genomic DNA was extracted and prepared from leucocytes using Biospin Blood Genomic DNA Mini-prep Kit (BioFlux, Iran) (Bubbon, 1985).

PCR analysis (Angeline, 2007) : PCR amplification of a 198 bp sequence of the MTHFR gene was performed as follows:

120 ng of genomic DNA was incubated in a $50 \mu \mathrm{L}$ containing both the forward and reverse primers for the MTHFR C677T SNP

The forward primers were:

5'-TGAAGGAGAAGGTGTCTGCGGGA-3' and the reverse primers were:

5'-AGGACGGTGCGGTGAGAGTG-3' ,50 $\mu \mathrm{M}$ each dNTP, standard PCR reaction buffer containing $1.5 \mathrm{mM}$ $\mathrm{MgCl}_{2}$ and 2.5UTaq DNA polymerase (Q.biogene, Illkirch, France). 
Amplification for the MTHFR C677T SNP was performed with an initial denaturation step at $93^{\circ} \mathrm{C}$ for 2 min in a thermal cycler (a Perkin Elmer 4800 thermal cycler (PTC-100 machine, MJ Research, Inc., Watertown, Mass. USA).

The PCR amplification conditions:

34 cycles consisting of $1 \mathrm{~min}$ denaturation at $94^{\circ} \mathrm{C}, 1 \mathrm{~min}$ annealing at $64^{\circ} \mathrm{C}$ and 1 min extension at $72{ }^{\circ} \mathrm{C}$. The final cycle included a 10-min extension step at $72^{\circ} \mathrm{C}$ in a thermal cycler (a Perkin Elmer 4800 thermal cycler (PTC-100 machine, MJ Research, Inc., Watertown, Mass. USA).

\subsubsection{Restriction enzyme analysis}

The MTHFR C677T SNP creates a Hinf I (Fermentas Life Sciences, Germany) restriction enzyme recognition sequence.

$10 \mathrm{ul}$ of the198-bp PCR product was digested with the restriction enzyme HinfI at $37^{\circ} \mathrm{C}$ for $3-4$ hours in the buffer. HinfI can recognize the C-T substitution in the fragments that causing a conversion of Ala to Val in the MTHFR encoding region. The two different alleles were designated T (Val) and C (Ala). The 198-bp fragment derived from the $\mathrm{C}$ allele is not digested by HinfI producing 198-bp fragment ,subjects of CC allele showed a DNA fragment of 198-bp. Whereas subjects with TT allele mutation showed the two DNA fragments of 175-bp and 23-bp as it was digested by HinfI . Subjects with TC showed three DNA fragments of 198-bp, 175-bp and 23-bp. The HinfI-treated PCR fragments were analyzed using 3\% agarose gel including $5 \mathrm{mg} / \mathrm{ml}$ ethidium bromide. To every $5 \mu \mathrm{l}$ of digested DNA product, $5 \mu \mathrm{l}$ of $6 \mathrm{X}$ gel loading dye (prepared by bromophenol blue $0.25 \%$ and sucrose $40 \%$ in $50 \mathrm{mM}$ EDTA). Running conditions at $85 \mathrm{w}$ for $6-8$ hours. 100 Base-Pair Ladder (Bioron) was $0.2 \mathrm{mg} / \mathrm{ml}$ in $10 \mathrm{Mm}$ Tris (pH 8.0), 1mM EDTA. Sub-marine gel electrophoresis was used, (Pharmacia Biotech by SEMKO AB, Sweden) using submarine chamber (Maxicell, EC 360 M-E-C apparatus Cooperation ST. Petersburg.Florida USA).

\subsection{The statistical analysis}

Results were statistically analyzed using SPSS 11.5 for Windows. The statistical data were calculated for mean, standard error (SE) and standard deviation (SD). Analysis of variance (ANOVA) was used to compare the results of all examined cases in all studied groups within group comparisons. The differences between mean values for each element were tested by student's " $t$ " test. The Hardy-Weinberg equilibrium or odds ratio (OR) and 95\% confidence interval (CI) for the presence of ischemic stroke within the MTHFR genotypes were analyzed by using the chi square $x^{2}$ test. Results were considered significant or non-significant when $P>$ or $<0.05$, respectively (Kirkwood, 1989).

\section{Results}

After restriction digestion with Hinf I, the C/C genotype resulted in198bp fragments, T/T genotype resulted in175 and 23bp fragments, the C/T genotype resulted in 3 fragments of 198,175 and 23bp. The 23 bp was too faint to be detected on agarose gel .Genotype and alleles frequencies for MTHFR are presented in table (2) and figure (1).

In controls (GroupI): the $\mathrm{C}$ allele frequency was $87.5 \%$, the $\mathrm{T}$ allele frequency was $12.5 \%$. The observed level of heterozygosity CT was in $15 \%$, the TT genotype was $5 \%$ and the CC genotype was the most common in controls (80\%).

In diabetic patients without IS(GroupII): the homozygous CC was found in 24 patients (60\%), the heterozygous CT in 10 patients (25\%) and the homozygous TT in 6 patients (15\%).Chi square $\left(X^{2}\right)$ for group $\mathrm{II}=4.143$ and there was non-significant association when compared to the controls $(\mathrm{P}=0.126) . \mathrm{C}$ allele frequency was $72.5 \%$ and $\mathrm{T}$ allele frequency was $27.5 \%$ when compared to controls there a significant association $\left(X^{2}=5.625, \mathrm{P}=\right.$ 0.018) (OR $=2.65$ with $95 \%$ CI of 1.164- 6.056) table3.

In diabetic patients with IS (Group III) :the CC pattern was found in 8 patients (20\%), the CT in 18 patients (45\%) and the TT pattern in 14 patients (35\%), there was a significant association when compared to the controls $\left(X^{2}=29.40, \mathrm{P}=0.000\right)$.C allele frequency was $42.5 \%$ and the $\mathrm{T}$ allele frequency is $57.5 \%$, with significant association when compared to controls $\left(X^{2}=35.60, \mathrm{P}=0.000\right)(\mathrm{OR}=9.471$ with $95 \% \mathrm{CI}$ of $\quad 4.267-21.018)$.

There was a significant association of genotype frequency in group III patients when compared to the group II patients $\left(X^{2=}\right.$ 13.486, $\left.\mathrm{P}=0.001\right)$. Frequency of $\mathrm{T}$ allele was more frequent in group III patients with significant association when compared to group II $\left(X^{2}=17.73, \mathrm{P}=0.000\right.$ with $\mathrm{OR}=3.567$ with $95 \% \mathrm{CI}$ of $\left.1.84-6.91\right)$.

In all studied groups, the CC pattern was found in 64 individuals (53.3\%), the CT in 34 subjects (28.3\%) and the TT pattern in 14 subjects (18.3\%).C allele frequency was $67.5 \%$ and the T allele frequency is $32.5 \%$ (table 2 ). 


\subsection{The relation between plasma Hcy and uric acid with genotype variants of C677T polymorphism of MTHFR}

Mean \pm SD of plasma Hcy levels related to different groups listed in table (1). The different genotypes in each group showed different means \pm SD of Plasma Hcy levels listed in table (4)and Figure(2). ANOVA test revealed a significant difference of the mean values of plasma Hcy level among different studied groups ( $\mathrm{F}=353.529, \mathrm{P}=0.000$ ). Plasma Hcy levels were significantly higher in group II and group III than control group $(\mathrm{t}=4.92, \mathrm{t}=22.22, \mathrm{P}=0.000)$ respectively with a significant increase in group III than group II $(\mathrm{t}=19.748$, $\mathrm{P}=0.000)$.

Mean \pm SD of plasma uric acid levels related to different groups listed in table (1). The different genotypes in each group showed different means \pm SD of Plasma uric levels listed in table (5). ANOVA test revealed a significant difference of the mean values of plasma uric acid level among different studied groups $(\mathrm{F}=278.52$, $\mathrm{P}=0.000)$. Plasma uric acid levels were significantly increased in group II and group III than group I $(\mathrm{t}=19.32, \mathrm{t}=$ $26.42, \mathrm{P}=0.000$ ) respectively with a significant increase in group III than group II ( $\mathrm{t}=10.40, \mathrm{P}=0.000)$.

There was a positive significant correlation between plasma Hcy, plasma uric acid levels and IS with a significant positive correlation between plasma Hcy and plasma uric acid in all studied groups $(\mathrm{r}=0.730, \mathrm{P}<0.05$ ) (Figure.3).

Table $(4,5)$ : There was a significant increase in the plasma Hcy and uric acid levels when comparing the 3 genotypes of MTHFR in all patient groups with their corresponding genotypes of control group and a significant increase on comparing the 3 genotypes of group III with the corresponding 3 genotypes of group II patients. In all patient groups, subjects with TT, TC genotypes have a significant increase of plasma Hcy and uric acid levels compared to CC genotype, with more significant increase in TT genotype.

\subsection{Data of lipid profile was listed in table 1}

Regarding total cholesterol (TC), there was a significant increase in group II and group III than controls ( $\mathrm{t}=$ $12.63, \mathrm{t}=14.75 \mathrm{P}=0.000$ ) respectively, with non-significant difference between group II and group III $(\mathrm{t}=-0.08, \mathrm{P}>0.05)$. LDL-C levels showed a significant increase in group II and group III than controls $(\mathrm{t}=$ 19.31, $\mathrm{t}=18.86, \mathrm{P}=0.000)$ respectively, with non-significant difference between group II and group III $(\mathrm{t}=-1.06$, $\mathrm{P}=0.294)$. HDL-C levels showed significant decrease in group II and group III than controls $(\mathrm{t}=6.917, \mathrm{t}=9.89$, $\mathrm{P}<0.001)$ respectively, with non-significant change among patient groups $(\mathrm{t}=1.71, \mathrm{P}>0.05)$. There was a non-significant association between lipid profile and the genotype pattern of the MTHFR $(P>0.05)$.

Regarding FBG levels, there was a significant increase in group II and group III when compared to controls ( $\mathrm{t}=$ $18.15,20.65, \mathrm{P}<0.0001)$ respectively with non-significant difference between group II and group III $(\mathrm{t}=-0.553$, $\mathrm{P}>0.05)$. There was non-significant association between FBG and the genotype pattern of the MTHFR $(\mathrm{P}>0.05)$.

\subsection{Table 6}

$X^{2}$ revealed non-significant difference referring to the effect of MTHFR genotypes on each of obesity, hypertension and smoking in two diabetic patient groups. In group III $\left(X^{2}=0.277, X^{2}=1.42, X^{2}=1.248, P>0.05\right)$ respectively and group II $\left(X^{2}=1.515, X^{2}=0.478, X^{2}=0.833, P>0.05\right)$ respectively.

This suggests that the C677T polymorphism in MTHFR gene, genotype TT and T allele are significantly associated with increase in plasma Hcy and plasma uric acid levels with increasing the risk of IS in diabetic Egyptian patients.

\section{Discussion}

There are multiple studies on samples of Egyptians to assess the prevalence and the risk factors for stroke, they have revealed that IS has the higher incidence when compared to hemorrhagic stroke (Hany et al.,2003 ).

In the present study a relatively missense mutation of MTHFR gene C677T SNP and a different genotype frequency were examined. In all studied groups the frequency of the MTHFR gene $\mathrm{C}$ allele was $67.5 \%$ while the $\mathrm{T}$ allele frequency was $32.5 \%$, the $\mathrm{C}$ allele frequency and the CC genotype of MTHFR are the most common in Egyptian healthy subjects. Also we noticed an association of both TT genotype and T allele frequencies at +677 in diabetic Egyptian patients suffered from IS when compared to the controls and diabetic patients without IS. These findings were in harmony with other studies of Kissela et al., 2005, Goracy et al., 2009, Biswas et al., 2009 and Moe et al., 2008.

However, controversial Indian (Kalita et al., 2006) and Turkish study (Dikmen M et al.,2006) revealed a nonsignificant difference in frequencies of MTHFR C677T genotypes between stroke patients and the control group. 
In an effort to determine the functional relevance of C677T MTHFR polymorphism, we examined the association of the genotype at +677 in MTHFR and Hcy plasma levels. We observed a significant increase in Hcy plasma levels in diabetic patient groups when compared to controls with more increase in diabetic patients with IS.

Moreover, we found that the different allelic variants of C677T MTHFR gene were significantly affecting Hcy plasma levels as there was a highly significant increase in the plasma Hcy levels towards TT and the CT carriers in each group. This result is consistent with Hermans et al., 2006, Angeline et al., 2009 and Sun et al., 2009. A large body of data has showed that the genetic variant (C677T) in the MTHFR gene is associated with peripheral, cerebral and coronary arteries (Ilhan et al., 2007) (Khandanpour et al., 2009).

Experimental evidence suggests that Hcy may contribute to both atherosclerotic and thrombotic processes by modulating vascular cell proliferation and promoting prothrombotic activity in the vascular wall (Outinen et al.,1998)(Upchurch et al., 1997).These effects of Hcy may explain the close correlation between the C677T mutation of MTHFR which results in hyperhomocysteinemia and the presence of atherosclerotic disease in DM (Sun et al., 2009).

The SNP in the MTHFR gene reduces the activity of MTHFR causing hyperhomocysteinemia (Spotila et al., 2003). The C677T SNP is thought to decrease the binding affinity of FAD to MTHFR and may increase the rate of dissociation of FAD from the enzyme, leading to the dissociation of the active dimer into monomers (Frosst et al., 1995) (Friedman et al., 1999) (Crott et al., 2001).

On the other hand, other investigators failed to find an association between the C677T MTHFR variant and IS (Ntaios et al., 2008) (Mueller et al., 2005) (Marie et al., 2007) (Endre et al., 2001) (Pasquale et al., 2002) (Harland et al., 2002) (Ehab Shaker et al., 2008). These conflicting results of different studies can be explained by the differences in study size and design, the ethnic or environmental differences of the subjects and the intake of folic acid, vit $\mathrm{B}_{6}$ or vit $\mathrm{B}_{12}$ which could ameliorate the effect of MTHFR on HCY levels and can also be explained by interaction with other genetic risk factors (Ganji et al., 2003) (Szolnoki and Melegh, 2006).

Another finding in our study was referring to plasma uric acid levels, we found that plasma uric acid levels were significantly increased in diabetic patients than controls with most significant increase in patients with IS that are carriers of TT and TC of MTHFR genotypes compared to CC genotype. It was positively correlated with plasma Hcy in all studied groups.

Our results are quite consistent with the observations of Motti et al., 1998 and Kim et al., 2002, Golbahar et al., 2007 and Simon et al., 2009. Other studies suggest that elevated serum uric acid can predict CVD and cerebrovascular accidents (Leo et al., 2004) (Newman et al., 2006) (Giacomo et al., 2009).

Possible mechanisms explain these associations: First, adenosine originating from S-adenosyl-Hcy, and incorporated into a precursor pool for uric acid, would link the syntheses of Hcy and uric acid (Malinow et al., 1995). Second, in subjects with the T/T genotype, renovascular atherosclerosis or the complications of systemic vascular disease may reduce the renal clearance of uric acid, resulting in elevated serum uric acid (Motti et al., 1998). Therefore, the MTHFR mutation may be a risk factor that is involved in multiple metabolic pathways related to vascular diseases (Hong et al., 2004).

In the present study concerning the identified risk factors for atherosclerosis and IS, there was a non-significant association between TC, LDL-C, FBG levels and HDL-C with the genotype pattern of the MTHFR genotypes $(\mathrm{P}>0.05)$.

We observed a non-significant difference referring to the effect of MTHFR genotypes on each of obesity, hypertension and smoking in two diabetic patients. Our results were comparable with Sun et al., 2009. On the other hand, Ilhan et al., 2008 who failed to find significant association between MTHFR SNP and coronary artery disease.

\subsection{Strengths and limitations}

One of the strength points of this study is the ethnic homogeneity of our sample, including all Egyptian people living in the same city having nearly same environmental factors. Moreover , we tried to estimate the influence of multiple risk factors e.g. obesity , HTN , smoking plasma uric acid and total lipid profile with HCY and MTHFR C677T SNP which are not included in most of other studies in Egypt, that making this study a good step for further researches in Egypt .

However, some study limitations need to be addressed. First, folic acid vit B6 and vit B12 plasma levels were not determined in the sample as they are not included in routine analysis in our hospital laboratory and hence, we 
could not investigate the possible correlation between them and MTHFR C677T SNP. Second, the results could be influenced by small size of the study group. Finally, our results do not determine the effect of gene-gene interaction between MTHFR and other corresponding genes (e.g. ACD I/D, Apo E and NOS 3 genes).

\section{Conclusions}

Our present observations allow us to suggest that the C677T polymorphism of the MTHFR gene, which is a leading cause of hyperhomocysteinemia and hyperuricemia , is one of the genetic factors predisposing to development of IS in type 2 diabetic Egyptian patients. However, we need further studies involving large sample of diabetic patients and study the effect of folic acid and vit B12 levels on plasma Hcy levels and to what degree they affect the vascular complications of type 2 DM and reduce the incidence of IS in type 2 DM in patients who carry the C677T allele.

Our results suggest that analysis of genotypes for the MTHFR C677T SNP may help to identify patients who are at higher risk of IS. It might also serve as an additional incentive for the initiation of an intervention trial with Hcy-lowering therapy. Extension from these studies may accelerate the discovery of new molecular targets for a future therapeutic intervention that gives us the hope to decrease the incidence of IS in type 2 diabetic patients.

\section{Acknowledgement}

We are grateful to the Medical Biochemistry Lab and Zagazig University Hospital Lab for technical assistance. Internal medicine Outpatient Clinics and Intensive Care Unit of Zagazig University Hospitals for recruitment of control subjects, and patients.

\section{References}

Aguilar, B., Rojas, J. C., \& Collados, M. T. (2004). Metabolism of homocysteine and its relationship with cardiovascular disease. J Thromb Thrombolysis, 18, 75-87. [Online] Available: http:// www.jn.nutrition.org

Angeline, T., Nirmala, J., \& Tsongalis, G. (2007). MTHFR Gene polymorphisms, B-vitamins and hyperhomocystinemia in young and middle-aged acute myocardial infarction patients. Exp Mol Pathol, 227-233. [Online] Available: http: //www.angelanand@yahoo.co.in

Angeline, T., Rita, M. A., Ramadevi, K., \& Mohan, G. (2005). Homocysteine status and acute myocardial infarction among Tamilians. Ind J Clin Biochem, 20 (1):18-20. [Online] Available: http://www.medind.nic.in/iaf

Angeline, T., Thiruvarutselvi, G., Isabel, W., Rita, M., Rama, D., \& Nirmala, J. (2009). MTHFR (ALA 222 VAL) polymorphism and AMI in patients with type 2 DM. Indian Journal of Clinical Biochemistry, 24 (2) 137-141. [Online] Available: http://www.medind.nic.in/iaf/

Araki, A. \& Sako, Y. (1987). Determination of free and total Homocysteine in human plasma by HPLC with $\begin{array}{llll}\text { fluorescence detection. Journal of } & \end{array}$ http://dx.doi.org/10.1016/0378-4347(87)80438-3

Assmann, G., Schriewer, H., Schmitz, G., \& Hagele, E. O. (1983). Quantification of high-density-lipoprotein cholesterol by precipitation with phosphotungstic acid/MgCl2. Clin Chem, 29, 2026-30. [Online] Available: http://www.ncbi.nlm.nih.gov/pubmed/6640896

Audelin, M. \& Genest, J. (2001). Homocysteine and cardiovascular disease in diabetes mellitus. Atherosclerosis, 159, 497-511. [Online] Available: http://www.sciencedirect.com

Bartels, H. \& Bohmer, M. (1972). Clin Chem Acta, 37-139.

Biswas, A., Ranjan, R., Meena, A., Akhter, M. S., Yadav, B. K., \& Munisamy, M. (2009). Homocystine levels, polymorphisms and the risk of ischemic stroke in young Asian Indians. J Stroke Cerebrovasc Dis, 18, 103-10. [Online] Available: http://www.bioline.org.br

Bubbon, G. J. (1985). Isolation of DNA from biological specimens without extraction with phenol. Clin.Chem, 31, 164. [Online] Available: http://www.ncbi.nlm.nih.gov/pmc/articles/PMC2800867/

Crott, J., Mashiyama, S., Ames, B., \& Fenech, M. (2001). MTHFR C677T polymorphism does not alter folic acid deficiency-induced Uracil incorporation into primary human lymphocyte DNA in vitro Cancer. Epidemiol Biomarkers Prev, 22, 1019-1025. [Online] Available: http://www.carcin.oxfordjournals.org. http://dx.doi.org/10.1093/carcin/22.7.1019

Dikmen, M., Ozbabalik, D., \& Gunes, H. (2006). Degirmenci Iand Bal C. Acute stroke in relation to homocysteine and MTHFR gene polymorphisms. Acta Neurol Scand, 113, 307-314. http://dx.doi.org/10.1097/WCO.0b013e3280148a97 
Ehab Shaker, Omar Amin El Serafy, Adel Hassanein Gad, Shahira El Shafie \& Amr Hasan. (2008). Thrombophilia in Patients with Cryptogenic Stroke. Egypt J. Neurol. Psychiat. Neurosurg, 45 (2), 549-60. [Online] Available: http://www.ejnpn.org/Article/ShowFullText.aspx?Id=387

Eikelboom, J., Hankey, G., Anand, S., Lofthouse, E., \& Staples, N. (2000). Association between high homocyst(e)ine and ischemic stroke due to large and small artery disease but not other etiologic subtypes of ischemic stroke. Stroke, 31, 1069-75. [Online] Available: http://www.ahajournals.org/cgi/. http://dx.doi.org/10.1161/01.STR.31.5.1069.

Endre, P., Tordai, A., Csornai, M., \& Nagy, Z. (2001). Hyperhomocysteinemia, MTHFR C677T mutation, methionin loading test in patients with stroke. The Journal Thrombosis and Haemostasis, 85, 334-339. [Online] Available: http://www.ejnpn.org/Article/ShowFullText.aspx?Id=387

Fossat, P., Prencipe, L., \& Berti, Q. (1980). Clin Chem, 26, 227. [Online] Available: http://www.linkinghub.elsevier.com/retrieve/pii/0039914086801011

Friedman, G., Goldschmidt, N., Friedlander, Y., Ben-Yehuda, A., Babaey, S., Mendel, M., \& Kidron, M. (1999). A common mutation A1298C in human MTHFR gene, Association with plasma total homocysteine and folate concentrations. Am Soc Nutr Sci, 129, 1656-61. [Online] Available: http://www.jn.nutrition.org/content/129/9/1656

Frosst, P., Blom, H. J., Milos, R., Goyette, P., Sheppard, C. A., Matthews, R. G., \& Boers, G. J. (1995) .Candidate genetic risk factor for vascular disease: a common mutation in MTHFR. Nat Gene, 10, 111-113. [Online] Available: http://www.ncbi.nlm.nih.gov/pubmed/7647779

Ganji, V. \& Kafai, M. (2003). Third National Health and Nutrition Examination Survey. Demographic, health, lifestyle, and blood vitamin determinants of serum total homocysteine concentrations in the third National Health and Nutrition Examination Survey. 1988-1994. Am J Clin Nutr, 77, 826-33. [Online] Available: http://www.jn.nutrition.org/external-ref?access_num=16140907

Gharib Fawi, Abed El Rahman A. Hassen, Azza Abdulnasser, Abed El Rouf Omar, Eman Abd El-Baset, A. El-Saye (2005). Southern Egypt Stroke Study. Egypt J. Neurol. Psychiat. Neurosurg, 42 (1): 255-269. [Online] Available: http://www.ejnpn.org/

Giacomo, Z ., Giovanni, T., Carlo, N., Vincenzo, S., Fabrizia, P., Michele, M., \& Enzo, B. (2009). Elevated Serum Uric Acid Concentrations Independently Predict Cardiovascular Mortality in Type 2 Diabetic Patients. Diabetes Care, 32, 1716-1720. [Online] Available: http://www.care.diabetesjournals.org. http://dx.doi.org/10.2337/dc09-0625

Golbahar, J., Aminzadeh, M. A., Al-Shboul, Q. M., Kassab, S., \& Rezaian, G. R. (2007). Association of methylenetetrahydrofolate reductase (C677T) polymorphism with hyperuricemia. Nutr Metab Cardiovasc Dis, 17 (6), 462-467

Goracy, L., Cyryowski, M., Kaczmarczyk, A., Fabian, D., Koziarska, J., \& Gorcy, A. (2009). C677T polymorphism of the methylenetetrahydrofolate reductase gene and the risk of ischemic stroke in Polish subjects. J Appl Genet, 50 (1), 63-67. [Online] Available: http//www.igor@sci.pam.szczecin.pl

Hany, Aref, Hana, N., \& Aida, Sh. (2003). Stroke Unite-Ain Shams University year 2002 July-September. Egyptian Stroke Journal, 1 (1), March. [Online] Available: http://www.ejnpn.org.

Harland, A., Marc, I., \& Holly, A. (2002). For the Genetics and Stroke in the Young Study Group: Cryptogenic Stroke in Relation to Genetic Variation in Clotting Factors and Other Genetic Polymorphisms Among Young Men and Women. Stroke, 33, 27-62. [Online] Available: http://www.ejnpn.org/Article/ShowFullText.aspx?Id=387

Hermans, M., Gala, J., \& Buysschaert, M. (2006). The MTHFR CT polymorphism confers a high risk for stroke in both homozygous and heterozygous T allele carriers with Type 2 diabetes, 23 (5), 529-36. [Online] Available: http://www.ncbi.nlm.nih.gov

Hong, Y., Lee, M., Kim, K., Lee, S., Lee, Y., Kim, B., Baekgeun, J., Hyeong, R. Y., Nishio, H., \& Kim, J. Y. (2004). The C677 Mutation in MTHFR gene: Correlation with Uric Acid and Cardiovascular Risk Factors in Elderly Korean men. J Korean Med Sci, 19, 209-13. [Online] Available: http:www.jykim@daunet.donga.ac.kr

Ilhan, N., Kucuksu, M., Kaman, D. \& Ozbay, Y. (2008). MTHFR polymorphism is associated with essential hypertension, coronary artery disease, and higher homocysteine levels. Arch Med Res, Jan; 39 (1), 125-30. http://dx.doi.org/10.1016/j.arcmed.2007.07.009. 
Kalita, J., Srivastava, R., Bansal, V., Agarwal, S, \& Misra, U. (2006). Methylenetetrahydrofolate reductase gene polymorphism in Indian stroke patients. Neurol India, 54, 260-263. [Online] Available: http://www.neurologyindia.com

Khandanpour, N., Willis, G., Meyer, F., Armon, M., Loke, Y., Wright, A., Finglas, P., \& Jennings, B. (2009). Peripheral arterial disease and methylenetetrahydrofolate reductase (MTHFR) C677T mutations: A case-control study and meta-analysis. J Vasc Surg, 49 (3), 711-8.

Kim, N., Kang, G., Kim, H., Kim, S., Nam, Y., Lee, S., Chung, H., Kang, S., \& Ahn, J. Y. (2002). Genetic polymorphisms of 5, 10-methylene-tetrahydrofolate reductase (MTHFR C677T and A1298C) in healthy Korean. Korean $J \quad$ Genet, $24, \quad$ 227-34. AOnline] Available: http://www.medfetch.com/loadresult2.php?sindex=40027\&limit=0\&limit2

Kirkwood, B. (1989). Essentials of medical statistics. Black well Scientific Publication, Oxford, London; P. 151.

Kissela, B., Khoury, J., Kleindorfer, D., Woo, D., Schneider, A., Alwell, K., Miller, R., Ewing, I., Moomaw, C., \& Broderick, P. (2005). Epidemiology of ischemic stroke in patients with diabetes: the Greater Cincinnati/Northern Kentucky Stroke Study. Diabetes Care, 28, 355-359. [Online] Available: http://www.ncbi.nlm.nih.gov/pubmed/15677792

Kothari, V., Stevens, R., Adler, A., Stratton, I., Manley, S., Neil, H., \& Holman, R (2002). Risk of stroke in type 2 diabetes estimated by the UK Prospective Diabetes Study risk engine. Stroke, 33, 1776-1781. [Online] Available: http://stroke.ahajournals.org/cgi/content/full/33/7/1776. http://dx.doi.org/10.1161/01

Leo, K., David, E., Kristiina, N., Georg, A., Hanna-Maaria, L. \& Jukka, T.(2004) .Uric Acid Level as a Risk Factor for Cardiovascular and All-Cause Mortality in Middle-aged Men. Arch Intern Med, 164, 1546-1551. [Online] Available: http://www.archinternmed.com

Malinow, M., Levenson, J., Giral, P., Nieto, F. J., Razavian, M., Segond, P., \& Simon, A. (1995). Role of blood pressure, uric acid, and hemorheological parameters on plasma homocystine oncentration. Atherosclerosis, 114, 175-83. [Online] Available: http://www.ncbi.nlm.nih.gov/pubmed/7605386

Malinow, M., Levenson, J., Giral, P., Nieto, F. J., Razavian, M., Segond, P., \& Simon, A. (1995). Role of blood pressure, uric acid, and hemorheological parameters on plasma homocyst(e)ine concentration. Atherosclerosis, 114, 175-83. [Online] Available: http://www.biomedlibsearch.com

Marie, S. K., Shinjo, S. K., Oba-Shinjo, S. M., De Silva, R., Barbosa, K. C., \& Yamamoto, F. (2007). Methylenetetrahydrofolate reductase gene polymorphism is not related to the risk of ischemic cerebrovascular disease in a Brazilian population. Clinics (Sao Paulo), 62, 295-300. [Online] Available: http://www.latunisiemedicale.com/article-medicale-tunisie_1413_fr

Moe, K. T., Woon, F. P., De Silva, D. A., Wong, P., Koh, T. H., \& Kingwell, B. (2008). Association of acute ischemic stroke with the MTHFR C677T polymorphism but not with NOS3 gene polymorphisms in a Singapore population. Eur J Neurol, 15, 1309-14. [Online] Available: http://www.pubget.com/paper/19049547

Motti, C., Gnasso, A., Bernardini, S., Massoud, R., Pastore, A., Rampa, P., \& Federici, G. (1998). Common mutation in methylenetetrahydrofolate reductase. Correlation with homocysteine and other risk factors for vascular disease. Atherosclerosis, 139, 377-83. [Online] Available: http://www.ncbi.nlm.nih.gov/pubmed/9712345

Mueller, T., Marschon, R., Dieplinger, B., Haidinger, D., Gegenhuber, A., Poelz, W., \& Webersinke, G. (2005). Factor V Leiden, prothrombin G20210A, and methylenetetrahydrofolate reductase C677T mutations are not associated with chronic limb ischemia: the Linz Peripheral Arterial Disease study. J Vasc Surg, 41 (5), 808-15. [Online] Available: http:// www.ncbi.nlm.nih.gov/pubmed/15886665

Newman, E., Rahman, F., Lees, K., Weir, C., \& Walters, M. (2006). Elevated serum urate concentration independently predicts poor outcome following stroke in patients with diabetes. Diabetes Metab Res Rev, 22, 79-82. [Online] Available: http://www.onlinelibrary.wiley.com. http://dx.doi.org/10.1002/dmrr.585

Ntaios, G., Savopoulos, C., Hatzitolios, A., Ekonomou, I., Destanis, E., \& Chryssogonidis, I. (2008). Homocysteine and carotid intima-media thickness in ischemic stroke patients are not correlated. Neuropsychiatr Dis Treat, 4, 477-9. [Online] Available: http://www.stroke-research.com/showabstract.php?pmid

Outinen, P., Sood, S., Liaw, P., Sarge, K., Maeda, N., \& Hirsh, J. (1998). Characterization of the stress-inducing effects of homocysteine. Biochem J, 332, 213-21. [Online] Available: http://www.bioline.org.br/pdf?ni09168 
Ozmen, B., Ozmen, D., Turgan, N., Habif, S., Mutaf, I., \& Bayindir, O. (2002). Association between homocysteinemia and renal function in patients with type 2 diabetes mellitus. Ann Clin Lab Sci, 32 (3), 279-86. [Online] Available: http://www.ncbi.nlm.nih.gov/pubmed/12175091

Pasquale, M., Valentino, S., \& Antonio, C. (2002). Hyperhomocysteinemia and Other Inherited Prothrombotic Conditions in Young Adults with a History of Ischemic Stroke. Stroke, 33, 51. [Online] Available: http://www.ahajournals.org/cgi/content/abstract/33/1/51?ck=nck

Perwaiz, M., Tasneem, F., Siddiqa, P., Farzana, A. Y., Majid, S., Naseema, M., Abrar, H., Iqbal, A., \& Philippe, M. (2005). Lack of association of methylenetetrahydrofolate reductase $677 \mathrm{C}>\mathrm{T}$ mutation with coronary artery disease in a Pakistani population. $J$ Mol Genet Med, 1 (1), 26-32. [Online] Available: http://www.libpubmedia.co.uk

Pollex, R., Mamakeesick, M., Zinman, B., Harris, S., Hanley, A., \& Hegele, R. (2005). Methylenetetrahydrofolate reductase polymorphism $677 \mathrm{C}>\mathrm{T}$ is associated with peripheral arterial disease in type 2 diabetes. Cardiovasc Diabetol, 7, 4-17. [Online] Available: http://creativecommons.org

Ralph, C. \& Jacobsen, D. (2001). Homocysteine in Health and Disease. Cambridge University Press, Cambridge, UK. 2001, 92-112. http://www.ndt.oxfordjournals.org

Simon, I., Yasuyuki, G., Koji, S., Sayo, K., Mariko, N., Yoshinori, I., \& Nobuyuki, H. (2009). Significant association between methylenetetrahydrofolate reductase $677 T$ allele and hyperuricemia among adult Japanese subjects. Nutr Res, 29 (10), 710-715. http://dx.doi.org/10.1016/j.nutres.2009.10.006

Spotila, L., Jacques, P., Berger, P., Ballman, K., Ellison, R., \& Rozen, R. (2003). Age dependence of the influence of Methylene tetrahydrofolate reductase genotype on plasma homocysteine level. Am J Epidemiol, 158, 871-877. [Online] Available: http://www.cnh.it/upload/prog_da_es/MTHFR_(12-06-2006)_44.pdf

Sun, J., Xu, Y., Lu. Hand, \& Zhu, Y. (2009). Polymorphism of the methylenetetrahydrofolate reductase gene association with homocysteine and ischemic stroke in type 2 diabetes. Neurol India, 57 (5), 589-593. [Online] Available: http://www.neurologyindia.com. http://dx.doi.org/10.4103/0028-3886.57808

Szolnoki, Z. \& Melegh, B. (2006). Gene-gene and gene--environment interplay represent specific susceptibility

Trinder, P. (1969). Determination of blood glucose using an oxidase-peroxidase method. Ann. Clin. Biochem, 1969, 624. [Online] Available: http://www.medind.nic.in/iaf

Ubbink, J., Vermaak, J., \& Bissbort, S. (1991). Rapid high-performance liquid chromatography assay for total homocysteine levels in human serum. $J$ chromatography, 565, 441-446. http://dx.doi.org/10.1016/0378-4347(91)80407-4

Upchurch, G., Welch, G., Fabian, A., Freedman, J., Johnson, J., Keaney, J., et al. (1997). Homocyst(e)ine decreases bioavailable nitric oxide by a mechanism involving glutathione peroxidase. J Biol Chem, 272, 17012-7. [Online] Available: http://www.findarticles.com/p/articles/mi_6875/is_4_6/ai /pg_5

Zhaohui, L., Sun, Li., Zhang, H., Liao, Y., Wang, D., Zhao, B., Zhu, Z., Zhao, J., Aiqun, Ma., Han, Y., \& Wang, Y. (2003). Elevated Plasma Homocysteine was Associated with Hemorrhagic and Ischemic Stroke, but Methylenetetrahydrofolate Reductase Gene C677T Polymorphism was a Risk Factor for Thrombotic Stroke A Multicenter Case-Control Study in China .AHA. Stroke, 34, 2085. [Online] Available: http://www.ahajournals.org/cgi 
Table 1. Comparison of clinical and laboratory data of the all studied groups (mean \pm SD and range, with anova test)

\begin{tabular}{|l|l|l|l|l|}
\hline & Group I & Group II & Group III & $\begin{array}{l}\text { F value } \\
\text { P value }\end{array}$ \\
\hline Sex & -19 females & -17 females & -18 females & F=0.099 \\
& -21 males & -23 males & -22 males & $\mathrm{P}=0.906$ \\
\hline $\begin{array}{l}\text { Age (years) } \\
\text { Range }\end{array}$ & $53.17 \pm 5.73$ & $52.81 \pm 5.44$ & $54.03 \pm 5.03$ & $\mathrm{~F}=0.541$ \\
\hline $\begin{array}{l}\text { Plasma HCY } \\
\text { levels } \\
(\mu \text { mol/L) }\end{array}$ & $42.0-63.0$ & $43.0-64.0$ & $45.00-63.0$ & $\mathrm{P}=0.584$ \\
\hline $\begin{array}{l}\text { Plasma uric acid } \\
\text { mg /dl }\end{array}$ & $4.62 \pm 0.681$ & $10.22 \pm 0.758^{*}$ & $18.12 \pm 2.58^{* *}$ & $\mathrm{~F}=353.529$ \\
\hline Total cholesterol & $2.50-10.70$ & $8.80-11.70$ & $14.30-24.30$ & $\mathrm{P}=0.000$ \\
(mg/dl) & $150.0-234.00$ & $228.00-401.00$ & $249.0-402.0$ & $\mathrm{P}=0.000$ \\
\hline LDL-C (mg/dl) & $151.17 \pm 36.36$ & $342.2 \pm 64.52$ & $348.75 \pm 65.07$ & $\mathrm{~F}=155.46$ \\
& $85.0-201.0$ & $210.0-440.0$ & $210.0-444.0$ & $\mathrm{P}=0.000$ \\
\hline HDL-C (mg/dl) & $57.77 \pm 6.77$ & $48.69 \pm 4.31$ & $47.02 \pm 3.16$ & $\mathrm{~F}=53.830$ \\
& $49.0-77.0$ & $40.0-57.5$ & $42.5-54.6$ & $\mathrm{P}=0.000$ \\
\hline FBG (mg/dl) & $87.25 \pm 12.9$ & $249.32 \pm 56.73$ & $255.07 \pm 53.29$ & $\mathrm{~F}=174.96$ \\
& $65.00-109.00$ & $143.00-312.00$ & $145.0-315.00$ & $\mathrm{P}=0.000$ \\
\hline
\end{tabular}

Table 2. Allele and genotype frequencies for MTHFR C677T polymorphism in all studied groups

\begin{tabular}{|l|l|l|l|l|l|}
\hline Groups & \multicolumn{2}{|l|}{ Genotype frequency n (\%) } & \multicolumn{2}{l|}{ Allele frequency n (\%) } \\
\hline & CC & CT & TT & C & T \\
\hline Group I & $32(80 \%)$ & $6(15 \%)$ & $2(5 \%)$ & $70(87.5 \%)$ & $10(12.5 \%)$ \\
\hline GroupII & $24(60 \%)$ & $10(25 \%)$ & $6(15 \%)$ & $58(72.5 \%)$ & $22(27.5 \%)$ \\
\hline GroupIII & $8(20 \%)$ & $18(45 \%)$ & $14(35 \%)$ & $34(42.5 \%)$ & $46(57.5 \%)$ \\
\hline All groups & $64(53.3 \%$ & $34(28.3 \%)$ & $22(18.3 \%)$ & $162(67.5 \%)$ & $78(32.5 \%)$ \\
& & & & & \\
\hline
\end{tabular}

Table 3. Chi square and OR (95\% CI) of MTHFR genotypes and allele frequency in all studied groups

\begin{tabular}{|l|l|l|l|}
\hline Groups & MTHFR Genotype & $\begin{array}{l}\text { C and T Allele } \\
\text { frequency }\end{array}$ & $\begin{array}{l}\text { OR of C and T allele } \\
\text { frequency 95\% CI }\end{array}$ \\
\hline Control group Vs & $X^{2}=4.143$ & $X^{2}=5.625$ & 2.65 \\
Group II & $P=0.126$ & $P=0.018$ & $1.164-6.056$ \\
\hline Control group Vs & $X^{2}=29.40$ & $X^{2}=35.60$ & 9.471 \\
Group III & $P=0.000$ & $P=0.00$ & $4.267-21.018$ \\
\hline GroupII Vs & $X^{2}=13.486$ & $X^{2}=17.73$ & 3.567 \\
Group III & $P=0.001$ & $P=0.000$ & $1.84-6.91$ \\
\hline
\end{tabular}


Table 4. Plasma HCY ( $\mu \mathrm{mol} / \mathrm{L})$ and different genotypes in all studied groups

\begin{tabular}{|l|l|l|l|l|l|}
\hline GroupI & $\begin{array}{l}\mathrm{CC} \\
\mathrm{n}=32\end{array}$ & $\begin{array}{l}\mathrm{CT} \\
\mathrm{n}=6\end{array}$ & $\begin{array}{l}\mathrm{TT} \\
\mathrm{n}=2\end{array}$ & - value & $P$ value \\
\hline Range $(\mu \mathrm{mol} / \mathrm{L})$ & $8.00-10.70$ & $9.70-10.30$ & $10.50-10.70$ & & \\
\hline Mean $\pm \mathrm{SD}$ & $9.50 \pm 0.681$ & $9.98 \pm 0.222$ & $10.6 \pm 0.141$ & & \\
\hline GroupII & $\begin{array}{l}\mathrm{CC} \\
\mathrm{n}=24\end{array}$ & $\begin{array}{l}\mathrm{CT} \\
\mathrm{n}=10\end{array}$ & $\begin{array}{l}\mathrm{TT} \\
\mathrm{n}=6\end{array}$ & $-1.64^{*}$ & $\mathrm{P}>0.05$ \\
\hline Range( $\mu \mathrm{mol} / \mathrm{L})$ & $8.80-10.90$ & $8.90-11.10$ & $10.80-11.70$ & $-5.47^{* *}$ & $\mathrm{P}=0.003$ \\
\hline Mean $\pm \mathrm{SD}$ & $9.97 \pm 0.647$ & $10.22 \pm 0.709$ & $11.25 \pm 0.32$ & $-4.42^{* * *}$ & $\mathrm{P}=0.007$ \\
\hline GroupIII & $\begin{array}{l}\mathrm{CC}=8 \\
\mathrm{n}=8\end{array}$ & $\begin{array}{l}\mathrm{CT} \\
\mathrm{n}=18\end{array}$ & $\begin{array}{l}\mathrm{TT} \\
\mathrm{n}=14\end{array}$ & $-2.470^{*}$ & $\mathrm{P}=0.04$ \\
\hline Range $(\mu \mathrm{mol} / \mathrm{L})$ & $14.30-16.60$ & $15.30-18.60$ & $15.30-24.30$ & $-8.56^{* *}$ & $\mathrm{P}=0.000$ \\
\hline Mean $\pm \mathrm{SD}$ & $15.53 \pm 0.831$ & $17.03 \pm 0.958$ & $20.98 \pm 1.97$ & $-6.94^{* * *}$ & $\mathrm{P}=0.000$ \\
\hline
\end{tabular}

*referred to $\mathrm{t}$-value of comparing CC with CT, **referred to $\mathrm{t}$-value of comparing CT with TT while ***referred to t-value of comparing CC with TT of patient groups.

Table 5. Plasma uric acid (mg/dl) and different genotypes in all studied groups

\begin{tabular}{|l|l|l|l|l|l|}
\hline GroupI & $\begin{array}{l}\mathrm{CC} \\
\mathrm{n}=32\end{array}$ & $\begin{array}{l}\mathrm{CT} \\
\mathrm{n}=6\end{array}$ & $\begin{array}{l}\mathrm{TT} \\
\mathrm{n}=2\end{array}$ & $t$-value & $p$ \\
\hline Range(mg/dl) & $2.60-6.20$ & $3.50-6.30$ & $5.40-6.20$ & & \\
\hline Mean \pm SD & $4.27 \pm 1.05$ & $5.35 \pm 1.16$ & $5.80 \pm 0.565$ & & \\
\hline GroupII & $\begin{array}{l}\mathrm{CC} \\
\mathrm{n}=24\end{array}$ & $\begin{array}{l}\mathrm{CT} \\
\mathrm{n}=10\end{array}$ & $\begin{array}{l}\mathrm{TT} \\
\mathrm{n}=6\end{array}$ & $-5.62^{*}$ & $\mathrm{P}=0.000$ \\
\hline Range(mg/dl) & $7.20-9.20$ & $7.90-9.50$ & $8.90-10.30$ & $-3.63^{* *}$ & $\mathrm{P}=0.015$ \\
\hline Mean \pm SD & $8.11 \pm 0.559$ & $8.88 \pm 0.559$ & $9.8 \pm 0.488$ & $-7.05^{* * *}$ & $\mathrm{P}=0.001$ \\
\hline GroupIII & $\begin{array}{l}\mathrm{CC} \\
\mathrm{n}=8\end{array}$ & $\begin{array}{l}\mathrm{CT} \\
\mathrm{n}=18\end{array}$ & $\begin{array}{l}\mathrm{TT} \\
\mathrm{n}=12\end{array}$ & $-4.54^{*}$ & $\mathrm{P}=0.003$ \\
\hline Range(mg/dl) & $7.90-9.10$ & $8.40-12.00$ & $10.40-12.40$ & $-3.37 * *$ & $\mathrm{P}=0.005$ \\
\hline Mean $\pm \mathrm{SD}$ & $8.45 \pm 0.414$ & $10.50 \pm 1.16$ & $11.42 \pm 0.665$ & $-9.37 * * *$ & $\mathrm{P}=0.000$ \\
\hline
\end{tabular}

*referred to $\mathrm{t}$-value of comparing CC with CT, **referred to $\mathrm{t}$-value of comparing CT with TT while ***referred to t-value of comparing CC with TT of patient groups

Table 6. Effect of MTHFR genotypes on some risk factors of IS in groupIII and groupII patients

\begin{tabular}{|c|c|c|c|c|}
\hline GroupIII & $\mathrm{N}$ & $\begin{array}{l}\text { Obesity } \\
\mathrm{N} \quad(\%)\end{array}$ & $\begin{array}{l}\text { Hypertension } \\
\mathrm{N} \quad \text { (\%) }\end{array}$ & $\begin{array}{l}\text { Smoking } \\
\mathrm{N} \quad(\%)\end{array}$ \\
\hline $\mathrm{CC}$ & 8 & $75 \%$ & $62.5 \%$ & $87.5 \%$ \\
\hline$\overline{\mathrm{CT}}$ & 18 & $66.6 \%$ & $83.3 \%$ & $72.2 \%$ \\
\hline TT & 14 & $64.5 \%$ & $71.5 \%$ & $85.7 \%$ \\
\hline$\overline{X^{2}}$ & & 0.277 & 1.429 & 0.69 \\
\hline $\mathrm{P}$ value & & $>0.05$ & $>0.05$ & $>0.05$ \\
\hline GroupII & $\mathrm{N}$ & $\begin{array}{ll}\text { Obesity } \\
\mathrm{N} \quad(\%)\end{array}$ & $\begin{array}{l}\text { Hypertension } \\
\mathrm{N} \quad \text { (\%) }\end{array}$ & \begin{tabular}{l}
\multicolumn{3}{l}{ Smoking } \\
$\mathrm{N} \quad(\%)$
\end{tabular} \\
\hline $\mathrm{CC}$ & 24 & $62.5 \%$ & $79.15 \%$ & $85.7 \%$ \\
\hline $\begin{array}{l}\mathrm{CT} \\
\mathrm{C}\end{array}$ & 10 & $40 \%$ & $70 \%$ & $88.8 \%$ \\
\hline TT & 6 & $50 \%$ & $83.3 \%$ & $75 \%$ \\
\hline$X^{2}$ & & 1.515 & 0.478 & 0.833 \\
\hline$P$ value & & $>0.05$ & $>0.05$ & $>0.05$ \\
\hline
\end{tabular}




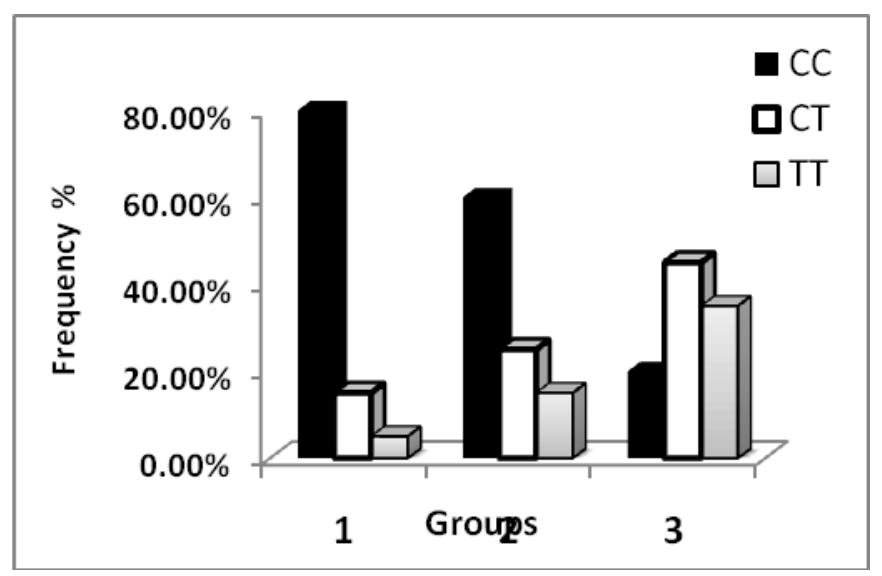

Figure 1. Frequency of MTHFR genotypes in all studied groups

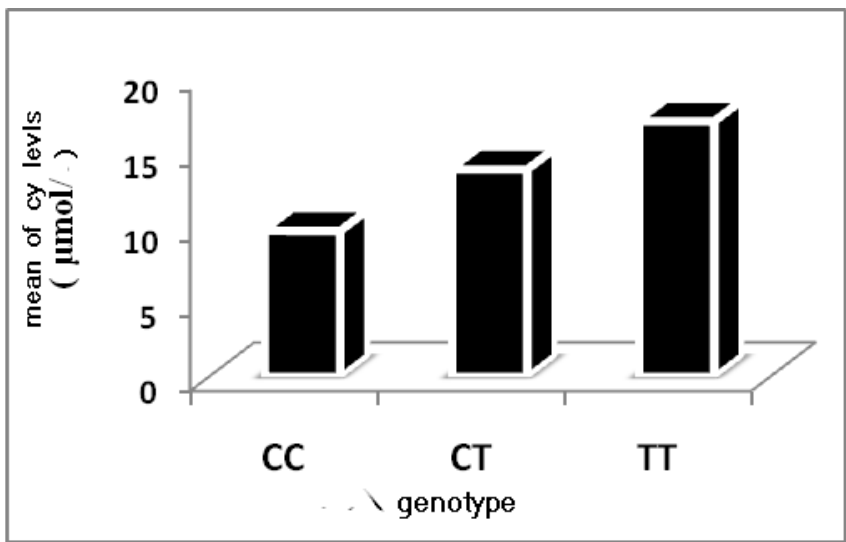

Figure 2. Mean of plasma Hcy levels in MTHFR genotypes in all studied groups

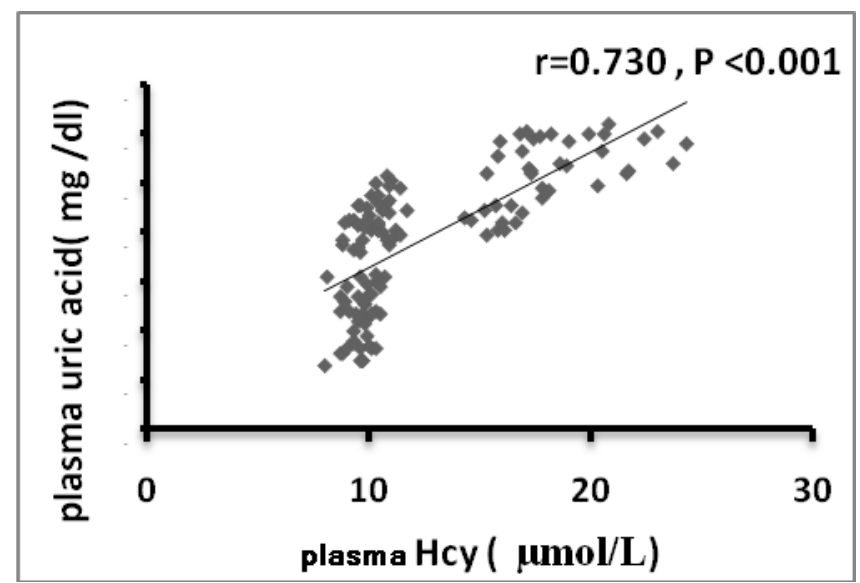

Figure 3. Correlation between of plasma Hcy and plasma uric acid levels in all studied groups 